\title{
Pemanfaatan Media Audio Visual Aids (AVA) Dalam Pembelajaran Kosakata Bahasa Inggris di TPA Jannatul Firdaus
}

\author{
Ratnawati ${ }^{{ }^{*}}$, Sulastri ${ }^{2}$ \\ 1, Akademi Bahasa Asing UMI Makassar \\ 2, Universitas Muslim Indonesia \\ ${ }^{1}$ ratnawati.ratnawati@umi.ac.id, ${ }^{2}$ sulastri.sulastri@umi.ac.id
}

\begin{abstract}
Abstrak
Pemanfaatan Audio Visual Aids (AVA) dalam Pembelajaran Kosakata bahasa Inggris melibatkan siswa TPA Jannatul Firdaus tepat untuk diimplementasikan bagi siswa khususnya di tingkat dasar. Pembelajaran Bahasa Inggris, khususnya ejaan, pelafalan dan penulisan membuat proses belajar lebih menarik dan efektif dengan memanfaatkan media AVA serta dapat membantu pemahaman siswa dalam pembelajaran. Pembelajaran kosakata Bahasa Inggris dengan memanfaaatkan AVA sesuai dengan kebutuhan anak dengan memperlihatkan gambar dan memperdengarkan pelafalan kosakata Bahasa Inggris secara langsung sehingga dapat mencapai target yaitu siswa berpartisipasi aktif, mampu melafalkan dan memahami kosakata Bahasa Inggris. IbM pengabdian yang dilakukan merupakan kegiatan yang bersinergi secara positif dengan masyarakat khususnya siswa TPA Jannatul Firdaus. Hasil kegiatan pengabdian menunjukkan hasil yang positif yang dapat dilihat dari antusias dan partisipasi siswa dalam setiap kegiatan.
\end{abstract}

Kata Kunci: media audio visual, kosakata Bahasa Inggris, TPA Jannatul Firdaus

\section{Pendahuluan}

Penguasaan Bahasa asing khususnya Bahasa Inggris menjadi syarat penting bagi anak bangsa agar mampu bersaing di era yang semakin maju. Hal ini seiring dengan usaha pemerintah dalam menyiapkan siswa yang handal sehingga mampu menghadapi persaingan global. Dalam Proses belajar, siswa pada tingkat sekolah dasar tentunya memiliki pola belajar yang berbeda dengan siswa tingkat menengah ataupun di perguruan tinggi. Umumnya, anak-anak memiliki rasa ingin tahu yang besar, butuh bergerak, senang bermain dan memiliki konsentrasi yang singkat sehingga dalam mengajar tidak cukup jika hanya dilakukan oleh tenaga pengajar saja tetapi juga diperlukan upaya dan alat yang dapat menunjang dan meningkatkan proses pembelajaran.

Pemanfaatan Audio visual Aids (AVA) dalam pembelajaran Bahasa Inggris sangat membantu dalam mengajarkan kosakata (vocabulary). Dengan AVA, siswa dapat melihat dan mendengar langsung materi yang disajikan dengan cara yang menarik, dapat menjadi sumber belajar yang autentik dan proses belajar anak akan lebih hidup (Ratnawati \& Angraeni, 2021). Salah satu cara yang dapat mewujudkan proses belajar 
yang sesuai bagi anak-anak adalah dengan menggunakan alat bantu media. Media menjadi komponen penting dalam pembelajaran terutama bagi anak-anak. Bretz dalam buku Arif S. Sadiman, dkk. (2002) menyimpulkan bahwa unsur utama dari media adalah unsur penglihatan, pendengaran dan gerakan. Ketiga unsur tersebut harus dapat dikombinasikan agar media dapat berfungsi secara maksimal.

Scott \& Ytreberg (1990:108) dalam Ramendra \& Ratminingsih (2007:3) mengemukakan bahwa cara utama untuk menyampaikan makna dalam proses pembelajaran Bahasa Inggris kepada anak-anak melalui alat bantu pembelajaran yang bervariasi, dalam hal ini adalah AVA. Pemanfaatan audio visual aids (AVA) secara aktif, proses belajar anak akan lebih mudah dan menarik.

Taman Pendidikan Alqur'an (TPA) Jannatul Firdaus yang berlokasi di Kota Makassar sekitar $4.5 \mathrm{~km}$ dari lokasi perguruan tinggi menjadi lokasi yang dipilih untuk melaksanakan pengabdian dengan pertimbangan bahwa TPA ini membina siswa dari tingkat TK dan SD belum dibekali dengan ilmu pengetahuan lain kecuali yang mereka peroleh di bangku sekolah. Selain itu, siswa di TPA Jannatul Firdaus belum familiar bahkan belum tersentuh dengan kegiatan semacam ini, sehingga para siswa begitu antusias dengan kegiatan pengabdian ini.

Berdasarkan temuan diatas, maka tim pengabdi kegiatan IbM merasa perlu untuk terjun langsung untuk berpartisipasi dan memberikan kontribusi agar para siswa dapat mengenal dan memahami kosakata Bahasa Inggris dengan memanfaatkan Auio Visual Aids (AVA).

\section{Metode Pelaksanaan}

Kegiatan IbM dengan memanfaatkan media audio visual (audio visual aids) dalam mengajarkan kosakata bahasa Inggris bagi siswa Tpengabdian sesuai dengan yang ada di lapangan meliputi kegiatan pelaksanaan pembelajaran Bahasa Inggris bagi siswa TPA Jannatul Firdaus berlokasi di Jl. Tinumbu Pannampu Blok D yang dimulai pada hari Rabu tanggal 21 November 2018 pada pukul 13.30 wita dan diikuti sebanyak 20 siswa serta tim pelaksana pengabdian yang terdiri atas dosen dan mahasiswa. Kegiatan tersebut berlangsung hingga tanggal 20 Januari 2019.

Kegiatan ini berlangsung selama 90 menit dengan jumlah pertemuan sebanyak sepuluh frekuensi dalam kurun waktu tiga (3) bulan. Berikut ini adalah materi yang diberikan kepada Siswa TPA Jannatul Firdaus.

\section{Mitra Kegiatan}

Taman Pendidikan ALqur'an (TPA) Jannatul Firdaus adalah mitra dalam kegiatan pengabdian kepada masyarakat (IbM) yang terletak di kota Makassar yang berjarak 4.5 km dari lokasi Perguruan Tinggi Akademi Bahasa Asing UMI Makassar dan diikuti oleh 20 siswa. 
Tabel 1. Jadwal Kegiatan dan Materi Pembelajaran Kosakata Bahasa Inggris

\begin{tabular}{lll}
\hline Hari/Tanggal & Pertemuan & Materi \\
\hline Senin/22 Juli 2019 & I & (Introduction: Greetings \\
Jum'at/ 26 Juli 2019 & II & Alphabet \\
Jum'at/ 02 Agustus 2019 & III & Number \\
Selasa/ 06 Agustus 2019 & IV & Fruits and Vegetables \\
Selasa/ 13 Agustus 2019 & V & School Objects \\
Selasa/ 20 Agustus 2019 & VI & Things in My House \\
Kamis/ 05 September 2019 & VII & Feeling \\
Kamis/ 19 September & VIII & Shapes \\
Kamis/ 26 September 2019 & IX & Daily Activities \\
Kamis/ 10 Oktober 2019 & X & Telling Time \\
\hline
\end{tabular}

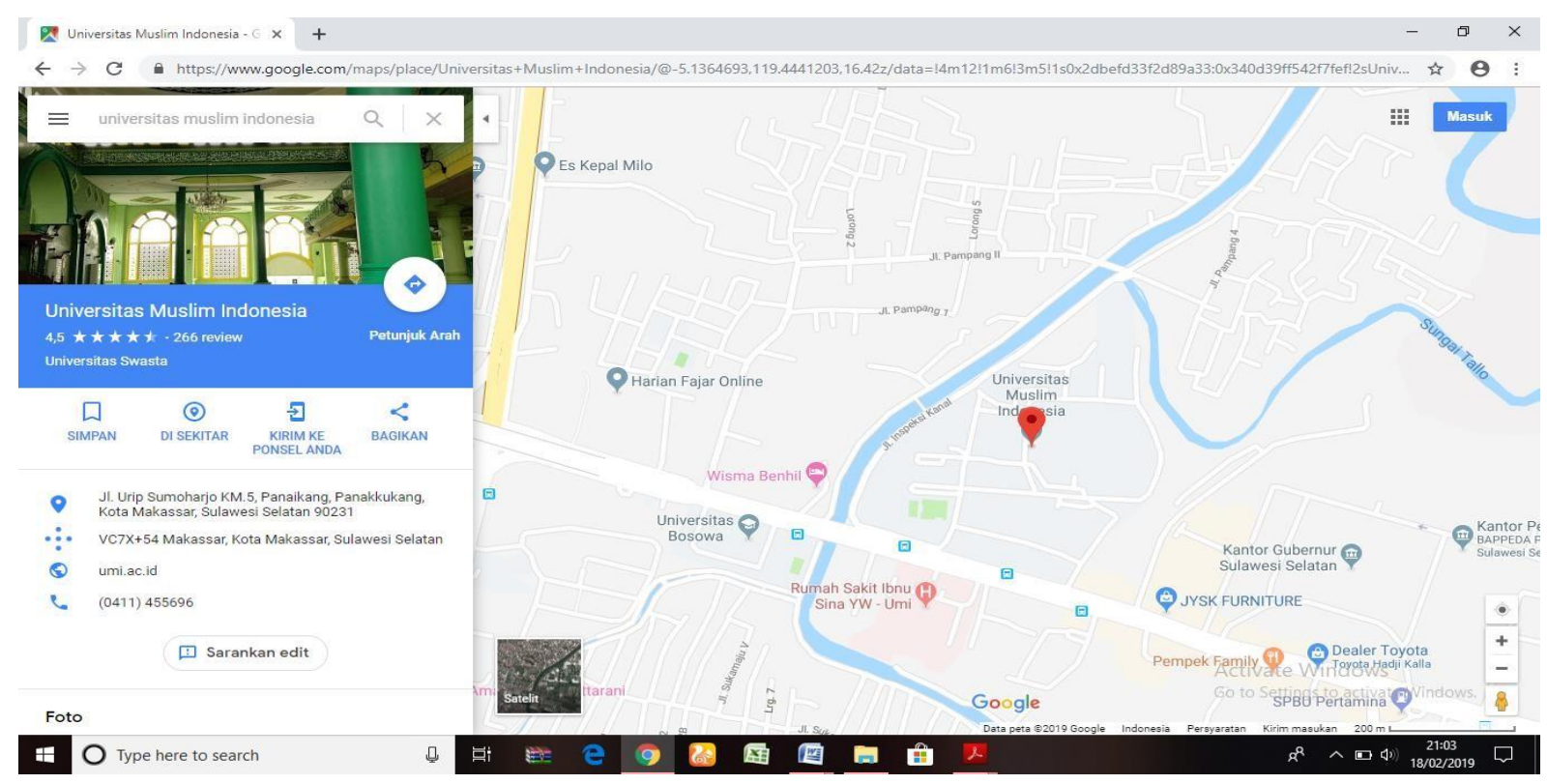

Gambar 1. Lokasi kegiatan

\section{Hasil dan Pembahasan}

Pembelajaran Bahasa Inggris dalam kegiatan ini memanfaatkan media audio-visual sebagai media dalam proses pembelajaran kosakata dengan tujuan meningkatkan kemampuan perbendaharaan kosakata Bahasa Inggris siswa. Pemanfaatan media dalam pembelajaran dapat meningkatkan daya konsentrasi siswadalam belajar dan sangat 
baikuntuk memperkenalkan bahasa dengan komponen kebahasaan seperti pelafalan dan kosakata yang disajikan secara real.

\section{Pertemuan Pertama}

Kegiatan pembelajaran dimulai pada hari Senin, tanggal 22 Juli 2019 di Masjid Jannatul Firdaus. Kegiatan ini diawali dengan perkenalan oleh tim pengabdi yang terdiri atas dosen dan mahasiswa dan mendorong anak-anak TPA untuk lebih termotivasi untuk belajar. Tim pengabdi mengingatkan kembali tentang materi Introduction: Greeting dengan memutar video greeting, lalu dilanjutkan dengan praktik per individu/siswa.

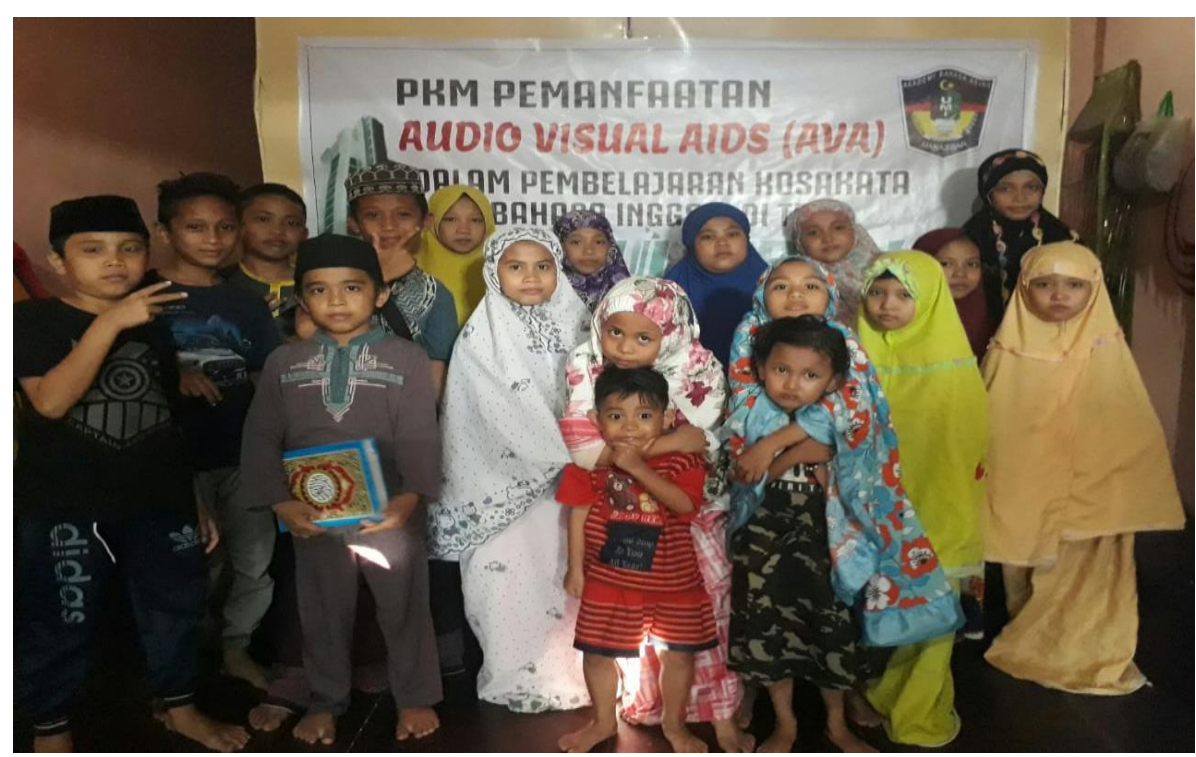

Gambar 2. Pertemuan Pertama

\section{Pertemuan Kedua}

Pertemuan kedua dilaksanakan pada hari Jum'at, 26 Juli 2019. Pada pertemuan kedua membahas tentang abjad (alphabet) untuk menyegarkan para siswa tentang materi tersebut. Tim pengabdi memutarkan lagu 'abjad' dengan menggunakan media AVA agar menambah daya tarik siswa dan konsentrasi siswa dalam belajar. Hal ini disesuaikan dengan kebutuhan siswa yang suka belajar sambal bermain.

Diakhir sesi pertemuan, para siswa mampu menunjukkan kemampuannya dalam memahami materi yang disajikan dengan respon dan partisipasi mereka dalam proses pembelajaran dan tanya-jawab.

\section{Pertemuan Ketiga}

Pertemuan ketiga dilaksanakan pada hari Jum'at, 02 Agustus 2019. Pembelajaran ini diawali dengan mengulang materi yang telah diberikan, kemudian dilanjutkan dengan materi angka (Number). Dalam penyajian materi, tim pengabdi selalu menampilkan video yang dapat dilihat dan didengar langsung oleh siswa yang diikuti dengan penjelasan yang diberikan oleh tim pengabdi. Dengan menggunakan media seperti ini, siswa secara langsung mengikuti apa yang mereka lihat dan dengar dan secara otomatis akan terbawa dalam kesehariannya.

Kegiatan selanjutnya, siswa dibagi menjadi beberapa kelompok dengan tujuan agar mereka dapat bekerjasama secara berkelompok/tim, setalah itu semua siswa praktek 
didepan sesuai dengan kelompok masing-masing. Untuk lebih meghidupkan susasana pembelajaran, tim pengabdi telah menyiapkan beberapa kuis dalam bentuk permainan yang mana siswa akan berlomba untuk menjawab angka-angka yang telah disediakan dalam bahasa Inggris. Bagi kelompok yang mampu menjawab pertanyaan dengan benar, mereka akan mendapatkan penghargaan (reward) alat tulis. Siswa terlihat antusias dengan materi yang disajikan. bahkan tim pelaksana sempat kebingungan pendapat siapa yang akan didengarkan.

\section{Pertemuan Keempat, Kelima dan Keenam}

Materi yang diberikan pada pertemuan ke empat, lima dan enam dilaksanakan pada tanggal 06, 13, dan 20 Agustus 2019 dengan materi yang diberikan yaitu Fruits and Vegetables, School objects dan Things in My House. Pada pertemuan keempat, tim pelaksana membuka pembelajaran dengan memperlihatkan sebuah gambar yang didalamnya terdapat buah dan sayuran. Kegiatan ini diawali dengan lagu tentang buah dan sayuran. Setelah itu, tim memberi pertanyaan berupa "What fruit is this?", "Do you like banana?". Siswa diminta untuk menyebutkan nama buah dan sayuran berdasarkan urutan abjad. Kegiatan selanjutnya, tim menyediakan kartu yang bergambar dan siswa harus menebak buah dan sayuran apa yang tertera pada kartu tersebut.

Pertemuan kelima diawali dengan bernyanyi kemudian dilanjutkan dengan materi baru yaitu School Objects yang berkenaan dengan benda yang ada di lingkup sekolah seperti book, pencil, pen. Tim pengabdi memperlihatkan dan memperdengarkan lagu kepada siswa dan menyanyikan lagu tersebut bersama-sama. Selanjutnya, siswa membentuk tim kemudian menyanyikan lagu tersebut. Hal ini bertujuan agar para siswa mampu membangun kepercayaan dirinya secara personal sehingga mereka percaya diri dan mau dalam setiap kegiatan. Lebih lanjut, tim pengabdi memberikan permainan yang bertemakan Cross and Match dimana siswa harus bekerja secara berkelompok.

Pertemuan keenam masih berkaitan dengan benda tetapi spesifik mengenai bendabenda yang ada di rumah (Things in My House). Tim pelaksana memperlihatkan beberapa gambar mengenai benda yang ada dirumah seperti bed, pillow, fridge dan lain-lain kemudian memberikan pertanyaan kepada siswa 'what is this?' ,'what is that?' and 'whose thing is this?'.

Bentuk kemampuan yang diperoleh oleh siswa yaitu siswa dapat memahami bentuk pertanyaan dan penggunaan kata 'this' serta kepemilikan dengan tepat 'my'. Para siswa secara bergantian diminta untuk menuliskan kata benda dalam bahasa Inggris sebanyakbanyaknya dengan memperhatikan penulisannya. Pada pertemuan ini, siswa sangat antusias mengikuti arahan yang diberikan selama proses belajar.

\section{Pertemuan Ketujuh}

Tim pelaksana membuka pembelajaran dengan memperlihatkan gambargambar/emoticon yang mengekspresikan perasaan seperti happy, angry, sad, sick dan lain-lain.

Dengan memanfaatkan media audio-visual dalam proses pembelajaran membuat siswa lebih antusias dan memperhatikan dengan seksama materi yang diberikan. Untuk menambah antusias siswa dalam belajar, tim memberikan permainan 'Matching Pictures'. Tim menyediakan kartu bergambar kemudian siswa menulis perasaan sesuai dengan 
gambar yang telah disiapkan di kartu tersebut. Tim pelaksana membagi 6 (enam) kelompok dalam permainan ini. Jika mereka bisa menulis dan mencocokkan dengan benar, maka mereka yang menjadi pemenang.

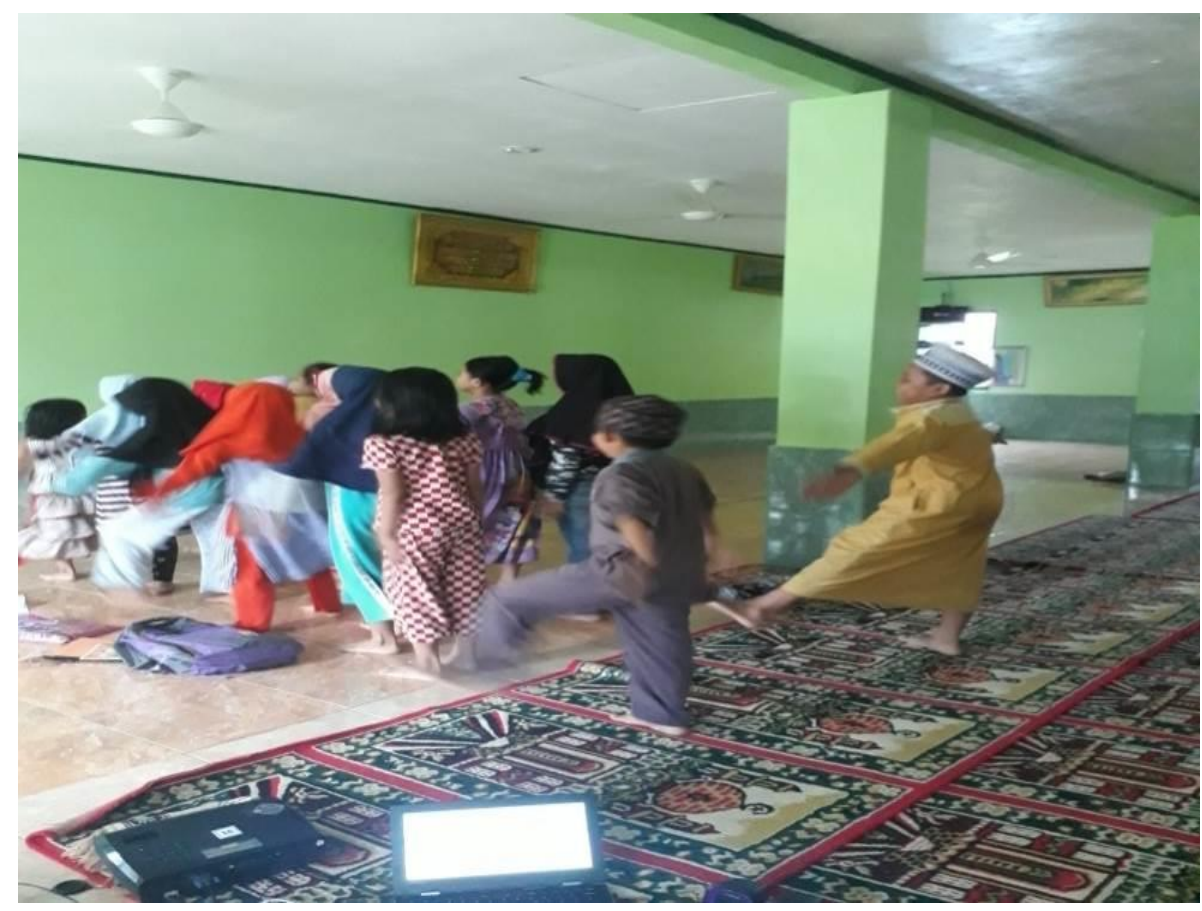

Gambar 3. Warming Up

\section{Pertemuan Kedelapan}

Pertemuan yang kesembilan dilaksanakan pada hari Kamis, 19 September 2019 dengan materi Shape (bentuk). Tim pelaksana menyiapkan materi yang telah disusun sebelumnya dan menyiapkan beberapa alat bantu berbentuk lingkaran, kotak, segitiga, bintang dan juga bentuk hati untuk ditunjukkan kepada siswa. Hal ini bertujuan untuk mengetahui pemahaman siswa mengenai bentuk/shape dan itu membuat mereka lebih mudah memahami materi yang diberikan karena disajikan secara autentik. Materi ini dikaitkan juga dengan materi sebelumnya yaitu warna sehingga dalam mengajarkan materi dapat dikombinasikan dengan materi sebelumnya sehingga selalu terjadi pengulangan-pengulangan dan memudahkan siswa mengingat kembali materi yang telah diberikan pada pertemuan sebelumnya.

\section{Pertemuan Kesembilan}

Pada pertemuan ini tanggal 26 September 2019, tim menyajikan materi mengenai 'Daily Activity' yang membahas tentang aktifitas keseharian. Dalam modul yang telah dibagikan, tim pengabdi menjelaskan mengenai berbagai aktifitas yang sering dilakukan misalnya wake up, go to school, do homework dan lain sebagainya. Penyampaian materi diselingi dengan permainan 'throwing ball'. Siswa melempar bola ke siswa yang lain, siswa yang menangkap bola harus menjawab pertanyaan sesuai dengan gambar/aktivitas yang diperlihatkan.

Selanjutnya, anggota tim pelaksana memberikan tugas kepada para siswa yaitu menuliskan aktifitas yang mereka lakukan secara berurutan. Kemampuan yang diperoleh dari peserta didik yakni: siswa mampu memahami aktifitas keseharian mereka. 


\section{Pertemuan Kesepuluh}

Tim pengabdi melaksanakan kegiatan pembelajaran pada hari Kamis, 10 Oktober 2019 dengan topik Telling Time. Materi ini diberikan untuk memperkenalkan siswa mengenai waktu dan jam dalam Bahasa Inggris. Dalam materi Telling time atau menceritakan waktu siswa belajar tentang bagaimana cara menceritakan atau menjelaskan waktu. Tim pengabdi menampilkan beberapa gambar jam dinding yang menunjukkan waktu yang berbeda-beda dengan cara yang sederhana. Kemudian memberikan pemahaman tentang konsep waktu dalam bahasa Inggris. Bentuk kemampuan yang diperoleh oleh siswa yaitu siswa dapat memahami bentuk pertanyaan dan penggunaan kata 'what time is it' dan 'it is ....'.

Dalam kegiatan ini siswa berkompetisi dengan bekerja tim untuk menjawab beberapa pertanyaan yang diberikan oleh tim pengabdi. Mereka secara bergantian diminta untuk menjawab soal dalam bahasa Inggris. Pada pertemuan ini, materi Telling Time dikolaborasikan dengan materi pada pertemuan sebelumnya yaitu materi Daily Activity. Siswa menyusun aktifitas kesehariannya dengan mencantumkan waktu dalam kegiatannya. Siswa sangat antusias mengikuti arahan yang diberikan selama proses belajar.

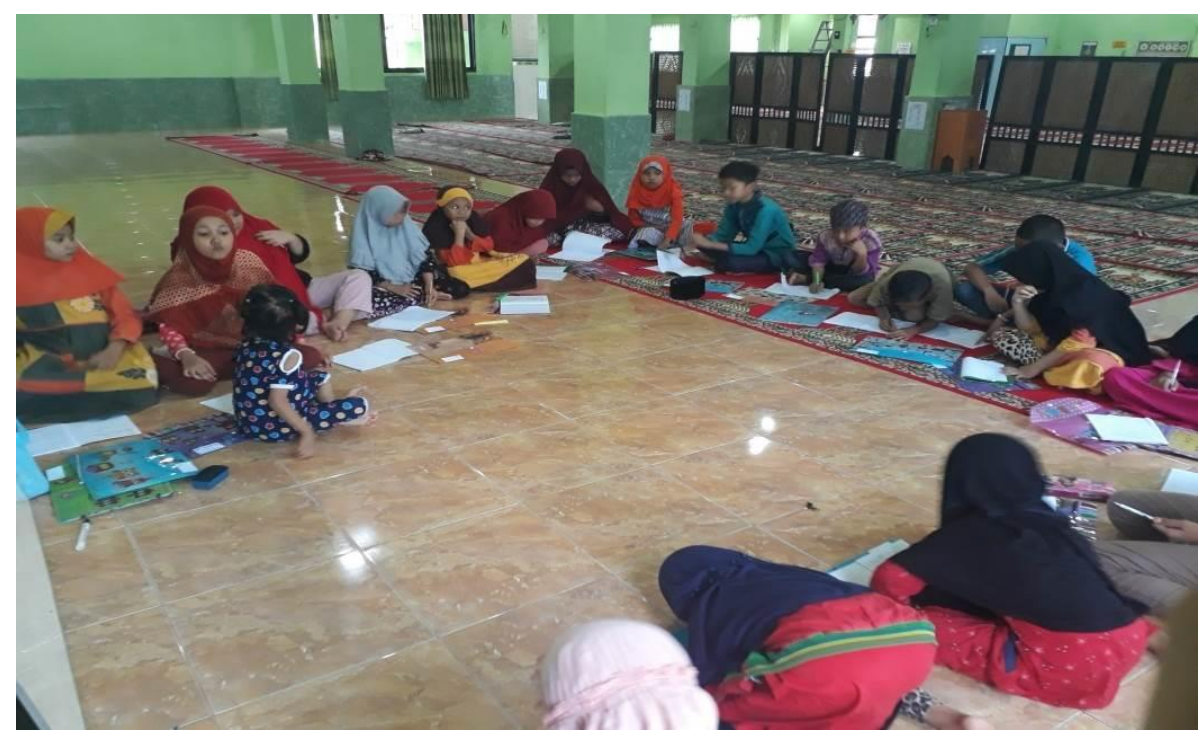

Gambar 4. Materi Pembelajaran Daily Activities

\section{Kesimpulan}

Berdasarkan hasil pelaksanaan kegiatan pengabdian masyarakat mengenai pemanfaatan Audio Visual Aids (AVA) dalam pembelajaran kosakata bahasa Inggris maka dapat disimpulkan bahwa media adalah satu satu strategi pembelajaran yang sangat cocok dalam mengajarkan bahasa Inggris khususnya kosakata untuk anak-anak sebagai sumber belajar yang autentik. Pemanfaatan media dalam pembelajaran dapat menambah daya konsentrasi siswa dalam belajar dan juga sangat baik untuk memperkenalkan bahasa dengan komponen kebahasaan seperti pelafalan dan kosakata yang disajikan secara real. Ini terlihat dari hasil kegiatan belajar siswa yang semakin meningkat di setiap pertemuan. Selain itu, semangat dan antusias siswa tergambar dengan jelas selama mengikuti proses pembelajaran bahasa Inggris. 


\section{Ucapan Terimakasih}

Terima kasih kepada Lembaga Pengabdian kepada Masyarakat (LPkM) Universitas Muslim Indonesia Makassar yang telah mendanai kegiatan pengabdian ini. Terima kasih juga kepada Pengurus Taman Pendidikan Alqur'an (TPA) Jannatul Firdaus sebagai mitra kegiatan pengabdian Pemamnfaatan Audio-Visual Aids dalam Pembelajaran Kosakata Bahasa Inggris di TPA Jannatul Firdaus.

\section{Referensi}

Brewster, J., Ellis, G., \& Girard, D. (2002). The Primary English Teacher's Guide. England: Penguin English

Ramendra, D. P., \& Ratminingsih, N. M. (2007). Pemanfaatan Audio Visual Aids (AVA) dalam proses belajar mengajar mata pelajaran Bahasa Inggris di sekolah dasar. Jurnal Penelitian dan Pengembangan Pendidikan, 1(2), 78-95.

Ratnawati, R., \& Angraeni, L. (2021). Pembelajaran Bahasa Inggris Berbasis Lagu dan Media Audio Visual. Madaniya, 2(1), 79-86. Retrieved from https://madaniya.pustaka.my.id/journals/contents/article/view/40

Sadiman, S. A. et al. (2002). Media Pendidikan (Pengertian, Pengembangan dan Pemanfaatannya). Jakarta: Raja Grafindo Persada. 